\title{
Soluble and Insoluble Fiber in Some Amazonian Fruits with Low Energy Density
}

\author{
Jaime Paiva Lopes Aguiar*, Francisca das Chagas do Amaral Souza \\ Coordination Society Environment and Health-CSAS, National Institute for Amazonian Research-INPA, \\ Manaus, Brazil \\ Email: ${ }^{*}$ jaguiar@inpa.gov.br
}

Received 30 May 2014; revised 5 July 2014; accepted 18 July 2014

Copyright (C) 2014 by authors and Scientific Research Publishing Inc.

This work is licensed under the Creative Commons Attribution International License (CC BY).

http://creativecommons.org/licenses/by/4.0/

(c) (i) Open Access

\begin{abstract}
Fruits are unarguably one of the main sources of dietary fiber, but are regional Amazonian fruits sources of dietary fiber? The objective of the present study was to assess the nutritional characteristics and fiber contents of fresh fruits with low energy density. The study fruits were abiu, bacuri, carambola, ingá-cipó, mapati, and taperebá acquired from the National Institute for Amazonian Research (INPA) and collected along kilometers 08 and 60 of highway BR174, AM-Brasil. Ash, protein, lipid, carbohydrate, energy and fiber contents were determined three times. The six fruits have very small and significantly different protein contents $(p<0.05)$. Taperebá and mapati presented the highest ( $4.65 \mathrm{~g})$ and lowest $(0.84 \mathrm{~g})$ fiber contents, respectively. Except for abiu $(0.49 \mathrm{~g})$, the low lipid contents of the study fruits confirmed their low energy density. The soluble fiber content of the fruits was generally low, being highest in taperebá (1.51 g). The insoluble fiber fraction prevailed in all six study fruits, with taperebá and mapati presenting the highest (3.14 g) and lowest $(0.65 \mathrm{~g})$ insoluble fiber contents, respectively. The dietary fiber contents show that the study fruits can contribute to the composition of diets with appropriate dietary fiber contents and low energy densities.
\end{abstract}

\section{Keywords}

Dietary Fiber, Regional Fruits, Proximate Composition

\section{Introduction}

Food habits strongly influence an individual's growth, development, and general health. Recent studies have shown that high-fiber diets protect against obesity, cardiovascular diseases, diabetes, and some types of cancer

"Corresponding author.

How to cite this paper: Aguiar, J.P.L. and Souza, F. das C. do A. (2014) Soluble and Insoluble Fiber in Some Amazonian Fruits with Low Energy Density. Food and Nutrition Sciences, 5, 1415-1419.

http://dx.doi.org/10.4236/fns.2014.514154 
[1] [2]. In this context, dietary fiber has been the target of scientific discussion and studied more intensely by nutrition and health experts, even though investigations about the role of fiber in the human body have been going on for a long time according to Cavalcante [3].

Dietary fibers are classified according to their solubility in water: insoluble fibers include cellulose, lignin, and some hemicelluloses, and their main functions are to: reduce bowel transit time, increase the fecal bolus, and help to reduce calorie intake, since they are highly satiating; and soluble fibers include pectin, gums, oligosaccharides, and some hemicelluloses, and they have specific functions in the human body, such as increasing bowel transit time, delaying gastric emptying, slowing glucose absorption, consequently reducing postprandial glycemia, and sequestering bile acids, consequently reducing serum cholesterol. The use of dietary fibers associated with other dietary factors can help to treat chronic noncommunicable diseases [4].

Dietary fiber analysis by enzyme assay provides information about the total fiber content and the soluble and insoluble fractions. The latter is important because the two fiber fractions have different physiological effects, as mentioned above.

Unfortunately there are few food composition tables in Brazil that include dietary fibers, two of them being the tables created by Menezes \& Lajolo [5] and Mendez et al. [6]. In Amazonas state, studies on the fiber composition of foods include Aguiar [7], indicating the need of more studies using newer methods to create a food composition table at the regional level, and consequently, at the national level. Fruits are unquestionably one of the main sources of dietary fiber, but are regional Amazonian fruits also sources of dietary fiber? In this context, the present study aimed to assess the fiber contents of the fruits abiu, bacuri, carambola, ingá-cipó, mapati, and taperebá.

The abiu tree, Pouteria caimito (Ruiz \& Pavon), is a plant from the Family Sapotaceae, considered native to the Brazilian, Colombian, Peruvian, and Venezuelan Amazon region [8]. Although its fruit is very popular, it is sometimes underappreciated because its peel contains white and viscous fluid that sticks to the lips. To this day the fruits are only consumed fresh [3].

Bacuri is a unilocular berry with a round, oval, or flat shape [3] [9]. It contains from one to five seeds surrounded by the endocarp, which is the edible part of the fruit [10]-[12]. The exocarp of the fruits varies widely, not only in size and color, but also in acidity. Some are very sweet, so normally eaten fresh. Some are very sour, and both the sweet and sour varieties are used in ice creams, juices, preserves, and puddings, among others [3].

The carambola tree belongs to the Family Oxalidaceae and is native to Southeast Asia [13] [14] where it is cultivated in gardens, parks, and houses. Although the fruits are very sour, they are consumed fresh. However, they are more widely used in juices, preserves, compotes, and jams, or pickled in vinegar [3].

The ingá-cipó tree is widely distributed in the West Indies, Central America, and South America, including all of Brazil, except perhaps the extreme south, and other countries in the north and east of the continent. According to Ducke [15], there are two varieties of the species Ingáedulis: the parvifolia and the typica. The latter, which corresponds to the description above, is the actual ingá-cipó. Its leaves are relatively large and the fruits are very long, thick, and seem to exist only in inhabited places where it is abundantly cultivated. The pulp that surrounds the seed is consumed fresh. Other uses for the fruit are unknown [3].

Mapati is native to the western area of Amazonas state (upper Rio Negro and Solimões rivers). It is widely cultivated by indigenous and nonindigenous peoples in the region, especially at the borders of Peru and Colombia; it abounds near Iquitos [16]. Mapatis are very similar to the common grape; even the bunch is similar, although mapatis are not as delicate. The fruits are eaten in a similar manner: by sucking the pulp and discarding the peels and seeds [3].

Taperebá belongs to the Family Anacardiaceae and is native to tropical America. It is found in all Brazilian regions and has many other popular names, such as cajazeiro, cajazeira, cajá, cajá-mirim, cajazeiro-miúdo, acajá, acajaíba, imbuzeiro, andsour cajá [3] [17]. The fruit is eaten fresh or used in juices, refreshments, ice cream, wine, and liqueurs.

The great health benefits of dietary fibers evidence the need of quantifying them in these species, so the main purpose of the present study was to determine the fiber content of some Amazonian fruits with low energy density.

\section{Material and Methods}

The fruits (Figure 1) abiu (Pouteria caimito), bacuri (Platonia insignis), carambola (Averrhoa carambola), 


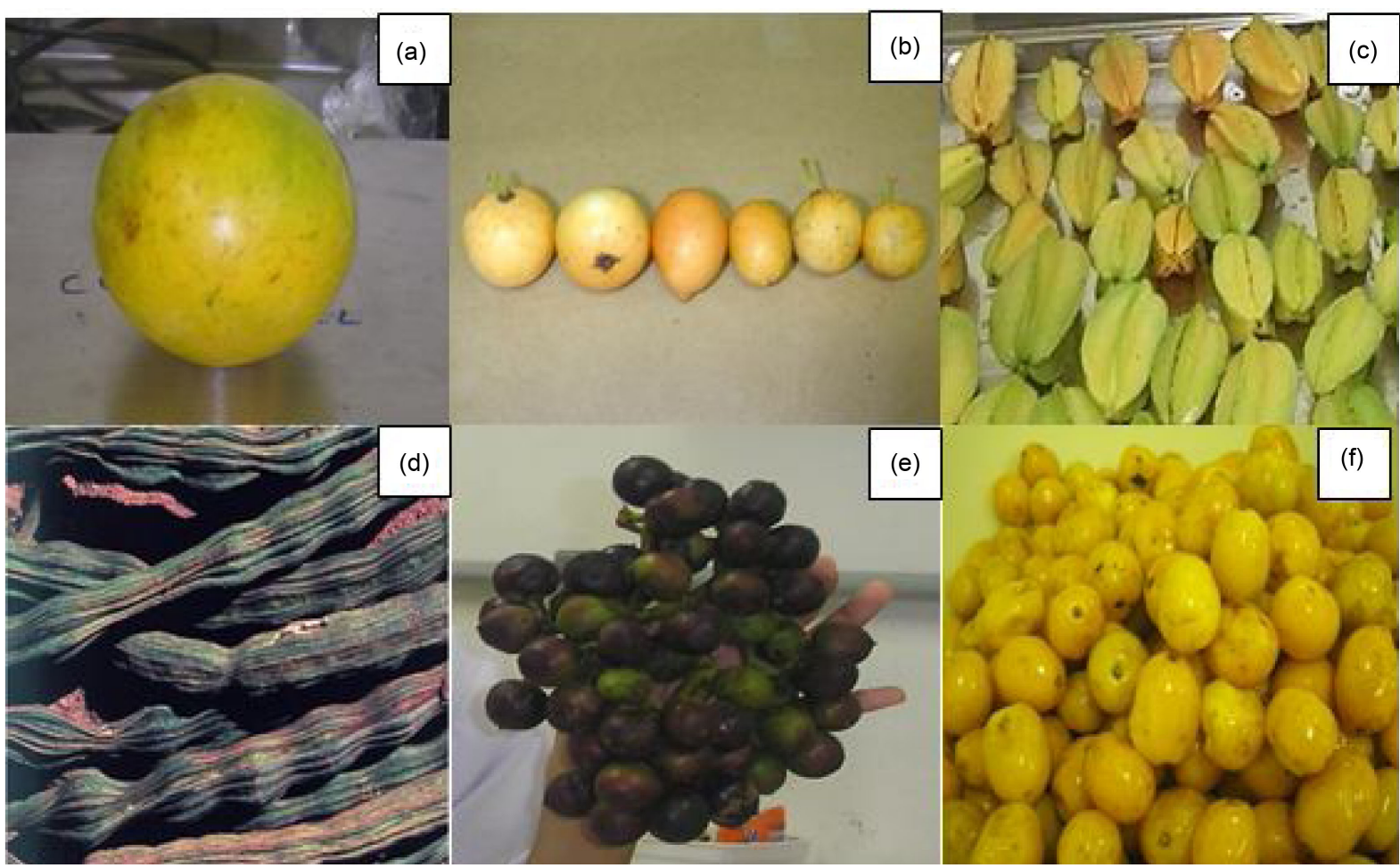

Figure 1. (a) Abiu (Pouteria caimito); (b) Bacuri (Platonia insignis); (c) Carambola (Averrhoa carambola); (d) Ingá-cipó (Ingá edulis); (e) Mapati (Pouromacecropeaefolia); and (f) Taperebá (Spondias mombim).

ingá-cipó (Ingá edulis), mapati (Pouromacecropeaefolia), and taperebá (Spondias mombim) were acquired from the National Institute for Amazonian Research (Instituto Nacional de Pesquisa da Amazônia, INPA) and collected along kilometers 08 and 60 of high way BR174, AM-Brasil, in maturation stages with characteristics of mature fruits.

After collection the fruits were transported to the Laboratory of Food and Nutrition (LAN) of the Coordination of Environmental Health Research Society (Coordenação de Pesquisa Sociedade Ambienteem Saúde, CSAS), where they were processed until the edible portion (pulp) was obtained. For this end, the fruits were selected, sanitized, and peeled, and the seeds were removed. The resulting pulp was freeze-dried to determine moisture. Once dehydrated, the fruits were ground in a porcelain mortar. Moisture content was determined by leaving the samples in a freeze-dryer (Edwards model F101-01-000, Inglaterra) until their weight stabilized. Next, the samples were pulverized and stored until analyses. Soluble and insoluble dietary fiber contents were determined by the enzymatic-gravimetric method developed by Asp et al. [18], which consists of submitting the samples using $\alpha$-amylase, pepsin and pancreatin [19]. This method does not determine fiber fractions, but it can distinguish between soluble and insoluble fiber after the lipids are extracted by a Soxhlet extractor using petroleum ether, as recommended by AOAC [20]. Ash content was determined gravimetrically using a muffle furnace at $550^{\circ} \mathrm{C}$, where the samples remained until their weights stabilized [20]. Protein content was determined by the micro-Kjeldahl method for total nitrogen using the factor 6.25 to convert total nitrogen into protein. Digestion was performed by a block digester (micro for 40 tubes) at $350^{\circ} \mathrm{C}$ until the color of the samples faded [20]. The lipid fraction was determined by an intermittent Soxhlet extractor using reagent-grade diethyl ether as solvent [20]. The carbohydrate fraction was given by difference after determination of the other fractions [20].

Energy on tent was given by multiplying the protein, lipid, and carbohydrate contents in grams by their heats of combustion (4.0, 9.0, and $4.0 \mathrm{kcal}$, respectively) [20]. The Tukey test analyzed the data at a significance level of $5 \%$.

\section{Results and Discussion}

Table 1 shows the proximate compositions of the fruits. In general, the study fruits presented high moisture 
content, and the moisture contents of bacuri and mapati were similar $(\mathrm{p}<0.05)$. The moisture content of mapati (89.88\%) was similar to the $92.10 \%$ reported by Aguiar [7]. Carambola presented the highest moisture content at 91.09\%, higher than the moisture reported by the Brazilian Food Composition Table [21].

All six study fruits had low ash content. Bacuri and taperebá had the lowest $(0.11 \mathrm{~g})$ and highest $(0.61 \mathrm{~g})$ ash contents, respectively. Carambola and mapati had similar ash contents at $0.2 \mathrm{~g}(\mathrm{p}>0.05)$.

Except for abiu ( $0.49 \mathrm{~g})$, the study fruits had very low and similar lipid contents, confirming their low energy density. Therefore, they are indicated for people who desire a low-fat diet. The lipid content of bacuri $(0.11 \mathrm{~g})$ (Table 1) was very different from the $2 \%$ reported by Franco [22].

The protein content of the study fruits is very small and would contribute very little to the daily recommendation of $0.80 \mathrm{~g}$ of protein $/ \mathrm{kg}$ of body weight suggested by the Dietary Reference Intakes [23]. Taperebá had the highest protein content at $0.95 \mathrm{~g}$, higher than the content reported by ENDEF [24], and mapati had the lowest at $0.29 \mathrm{~g}$, similar to the content of $0.30 \mathrm{~g}$ reported by Aguiar [7].

Table 1 shows that taperebá had the highest fiber content $(4.65 \mathrm{~g})$ of the study fruits, higher than other low-calorie fruits such as pineapple (1 g) and cajá-manga (2.6 g). Mapati had the lowest fiber content at $0.84 \mathrm{~g}$. According to the DRIs [23], an adult male requires 16.5 to $17.9 \mathrm{~g}$ of fiber per day, and an adult female, 12.1 to $13.8 \mathrm{~g}$ per day.

The study fruits are low carbohydrate since their carbohydrate contents do not even correspond to the minimum daily recommendation of 220 to $330 \mathrm{~g} / \mathrm{d}$ for men and 180 to $230 \mathrm{~g} / \mathrm{d}$ for women [23].

The study fruits can be considered low calorie because of their low energy contents, reflecting their high moisture and low fat contents [7]. Ingá-cipó had the highest energy content (83.80 kcal), followed by abiu (71.82 kcal), which differs from the $62 \mathrm{kcal}$ reported by TACO [21]. The energy content of carambola (25.17 kcal) was similar to the $33 \mathrm{kcal}$ reported by Phillippi [25].

Table 2 shows the fiber content of the fruits in detail. The soluble fiber content of these fruits was generally low. Taperebá had the highest soluble fiber content at $1.51 \mathrm{~g}$, significantly higher than those of the other study fruits $(\mathrm{p}<0.05)$. All study fruits had higher insoluble fiber content than soluble fiber content. Taperebá and mapati had the highest $(3.14 \mathrm{~g})$ and lowest $(0.65 \mathrm{~g})$ insoluble fiber contents, respectively.

\section{Conclusion}

The dietary fiber contents found by the present study show that the study fruits can contribute to the composition of diets with appropriate levels of dietary fiber and low energy densities, and promote their inclusion in the diet

Table 1. Proximate composition of $100 \mathrm{~g}$ of the edible portion (whole matter).

\begin{tabular}{|c|c|c|c|c|c|c|}
\hline & Abiu & Bacuri & Carambola & Ingá-cipó & Mapati & Taperebá \\
\hline Moisture (\%) & $82.38 \pm 0.29^{a}$ & $89.31 \pm 0.29^{b}$ & $91.09 \pm 0.22^{c}$ & $78.81 \pm 0.20^{d}$ & $89.88 \pm 0.24^{b}$ & $85.04 \pm 0.04^{\mathrm{e}}$ \\
\hline Ash (g) & $0.28 \pm 0.02^{\mathrm{c}}$ & $0.11 \pm 0.00^{\mathrm{e}}$ & $0.2 \pm 0.00^{\mathrm{d}}$ & $0.34 \pm 0.00^{\mathrm{b}}$ & $0.2 \pm 0.00^{\mathrm{d}}$ & $0.61 \pm 0.01^{\mathrm{a}}$ \\
\hline Proteins (g) & $0.81 \pm 0.01^{\mathrm{b}}$ & $0.57 \pm 0.01^{d}$ & $0.43 \pm 0.01^{\mathrm{e}}$ & $0.72 \pm 0.02^{\mathrm{c}}$ & $0.29 \pm 0.01^{\mathrm{f}}$ & $0.95 \pm 0.01^{\mathrm{a}}$ \\
\hline Lipids (g) & $0.49 \pm 0.02^{\mathrm{a}}$ & $0.11 \pm 0.00^{c}$ & $0.07 \pm 0.00^{\mathrm{d}}$ & $0.08 \pm 0.00^{\mathrm{cd}}$ & $0.03 \pm 0.00^{\mathrm{e}}$ & $0.24 \pm 0.02^{b}$ \\
\hline Total fiber (g) & $1.69 \pm 0.01^{\mathrm{d}}$ & $2.10 \pm 0.08^{\mathrm{cd}}$ & $2.50 \pm 0.20 b^{c}$ & $2.58 \pm 0.04^{\mathrm{b}}$ & $0.84 \pm 0.11^{\mathrm{e}}$ & $4.65 \pm 0.10^{\mathrm{a}}$ \\
\hline Carbohydrates & $14.35 \pm 0.00^{b}$ & $7.8 \pm 0.01^{\mathrm{d}}$ & $5.71 \pm 0.01^{\mathrm{f}}$ & $17.48 \pm 0.02^{\mathrm{a}}$ & $8.77 \pm 0.01^{\mathrm{e}}$ & $8.51 \pm 0.01^{\mathrm{c}}$ \\
\hline Energy (Kcal) & $65.06 \pm 0.20^{\mathrm{b}}$ & $34.47 \pm 0.00^{\mathrm{d}}$ & $25.17 \pm 0.03^{f}$ & $73.5 \pm 0.02^{\mathrm{a}}$ & $36.52 \pm 0.01^{\mathrm{e}}$ & $39.99 \pm 0.14^{\mathrm{c}}$ \\
\hline
\end{tabular}

Same letters in lines indicate that the differences are not significant at the $5 \%$ level according to the Tukey’s test.

Table 2. Soluble and insoluble fiber contents of the study fruits (whole matter).

\begin{tabular}{ccc}
\hline & Soluble fiber $(\mathrm{g})$ & Insoluble fiber $(\mathrm{g})$ \\
\hline Abiu & $0.44 \pm 0.06^{\mathrm{c}, \mathrm{d}}$ & $1.25 \pm 0.07^{\mathrm{b}, \mathrm{c}}$ \\
Bacuri & $0.76 \pm 0.23^{\mathrm{b}, \mathrm{c}}$ & $1.34 \pm 0.31^{\mathrm{b}}$ \\
Carambola & $0.83 \pm 0.02^{\mathrm{b}}$ & $1.68 \pm 0.18^{\mathrm{b}}$ \\
Ingá-cipó & $0.00 \pm 0.00^{\mathrm{e}}$ & $2.58 \pm 0.04^{\mathrm{a}}$ \\
Mapati & $0.19 \pm 0.01^{\mathrm{d}, \mathrm{e}}$ & $0.65 \pm 0.11^{\mathrm{c}}$ \\
Taperebá & $1.51 \pm 0.01^{\mathrm{a}}$ & $3.14 \pm 0.11^{\mathrm{a}}$ \\
\hline
\end{tabular}

Same letters in lines indicate similar contents at the 5\% significance level according to the Tukey’s test. 
of the Amazonian population.

\section{Acknowledgements}

We thank Conselho Nacional de Desenvolvimento Científico e Tecnológico (CNPq) for sponsoring the study and the "ad hoc" reviewers of this article for their valuable suggestions and corrections.

\section{References}

[1] Key, T.J., Allen, N.E., Spencer, E.A. and Travis, R.C. (2003) The Effect of Diet on Risk of Cancer. Lancet, 360, 861868. http://dx.doi.org/10.1016/S0140-6736(02)09958-0

[2] World Health Organization (2003) Diet, Nutrition and the Prevention of Chronic Diseases. Report of a Joint WHO/ FAO Expert Consultation, World Health Organization, Geneva.

[3] Choi, P.B. (1996) Edible Fruits of the Amazon. CNPq/Goeldi Museum (Collection Adolpho Ducke), Bethlehem, 279.

[4] Costa, R.P., Silva, C.C. and Magnoni, D.R. (1997) Importance of Fiber in Preventing Cardiovascular Diseases. Review Brazilian Clinical Nutrition, 12, 151-154.

[5] Menezes, E.W. and Lajolo, F.M. (2000) Contained in dietary fiber resistant starch in foods y productos y Iberoamerican. Proyeto CYTED XI.6 "Characterization of Obtencion y suaplicacion for dietary fiber in foods especialesrigimenes”. DOCUPRINT, São Paulo, 121.

[6] Mendez, M.H.M., Derivable, S.C.N., Rodrigues, M.C.R. and Fernandes, M.L. (1995) Table of Food Composition. EDUFF, Niterói, 41.

[7] Aguiar, J.P.L. (1996) Table of Food Composition Amazon. Amazon Minutes, 26, 121-126.

[8] Manica, I. (2000) Native, Wild and Exotic Fruits 1. Five Continents, Porto Alegre, 327.

[9] Guimarães, A.D.G., Mota, M.G. and Nazareth, R.F.R. (1992) Collecting Germplasmbacuri (Platonia insignis Mart.) In the Amazon. I. Campos microregion Marajó (Soure/Salvaterra). Research Bulletin, 132, 23.

[10] Carvalho, J.E.U., Birth, W.M.O. and Müller, C.H. (1998) Physical and Germination of Native Fruit Species of Amazon Features. Research Bulletin, 203, 18.

[11] Mourao, K.S.M. and Beltrati, C.M. (1995) Morphology of Fruits, Seeds and Seedlings Platonia insignis Mart. (Clusiaceae). I. Anatomical Fruit and Seed Development Aspects. Manaus: Amazon ACTA. Manaus, 25, 11-32.

[12] Mourao, K.S.M. and Beltrati, C.M. (1995) Morphology of Fruits, Seeds and Seedlings Platonia insignis Mart. (Clusiaceae). II. Anatomical Fruit and Seed Development Aspects. Manaus: Amazon ACTA. Manaus, 25, 33-46.

[13] Lennox, A. and Ragoonath, J. (1990) Carambola and Bilimbi. Fruits, 45, 497-501.

[14] Nakasone, H.K. and Paull, R.E. (1998) Tropical Fruits. CAB International, Wallingford, 132-148.

[15] Ducke, A. (1949) Notas on neutrópica flora II. As legumes of the Brazilian Amazon. Report Technological Institute Agronomic, Belém-Pará-Brazil, 8, 128.

[16] Ducke, A. (1946) Plants of Pre-Columbian Culture in the Brazilian Amazon; Notes on Species or Spontaneous Forms Alleged to Have Given Rise to Them. Report Technological Institute Agronomic, 18, 249.

[17] Braga, R. (1976) Cajazeira. In: Braga, R., Ed., Plants of the Northeast, Especially in Ceará, ESAM, Mossley, Mossorense Collection, 42, 103.

[18] Asp, N.G., Johansson, C.G., Hallmer, H. and Siljestrom, M. (1983) Rapid Enzymatic Assay of Insoluble Dietary Fiber. Journal of Agricultural and Food Chemistry, 31, 43-53. http://dx.doi.org/10.1021/jf00117a003

[19] Filizetti-Cozzi, T.M.C.C. and Lajolo, F.M. (1991) Dietary Fiber Insoluble, Soluble and Total in Brazilian Foods. Review Pharmacy Biochemistry, University São Paulo, 27, 83-99.

[20] AOAC (Association of Official Analytical Chemists) (1995) Official Methods of Analyzes. 16th Edition, Arlington.

[21] TACO (2006) Table of Food Composition.

[22] Franco, G. (1992) The Chemical Composition of Foods. 8th Edition, Sao Paulo, 111-116.

[23] Dietary Reference Intakes (DRIs) (2005) Recommended Intakes for Individual, Elements. Food and Nutrition Board, Institute of Medicine, National Academies.

[24] ENDEF (1977) Table of Food Composition. IBGE.

[25] Philippi, S.T. (2001) Table of Food Composition: Nutritional Support for Decision. Sao Paulo, 22. 
Scientific Research Publishing (SCIRP) is one of the largest Open Access journal publishers. It is currently publishing more than 200 open access, online, peer-reviewed journals covering a wide range of academic disciplines. SCIRP serves the worldwide academic communities and contributes to the progress and application of science with its publication.

Other selected journals from SCIRP are listed as below. Submit your manuscript to us via either submit@scirp.org or Online Submission Portal.
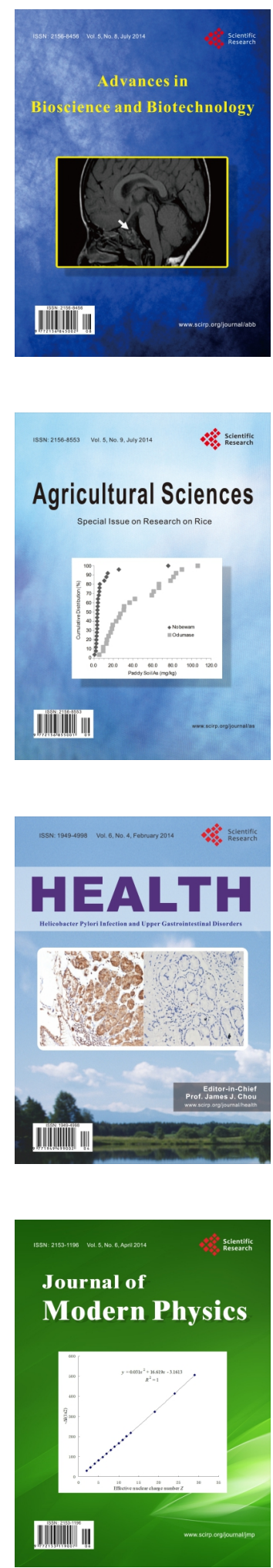
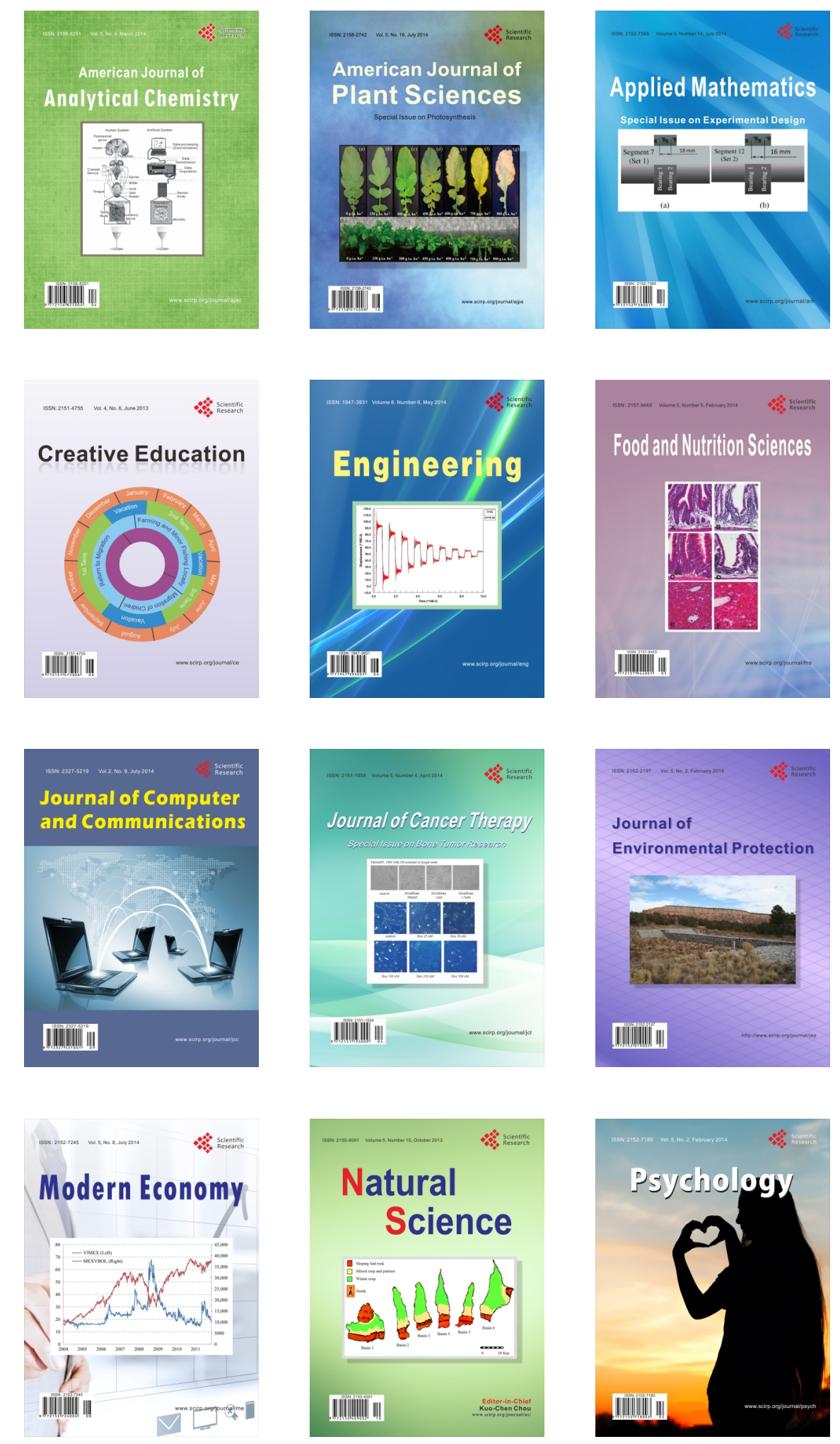